\title{
Knowledge transfer activities of scientists in nanotechnology
}

\author{
Kasia Zalewska-Kurek ${ }^{1}$ (D) Klaudia Egedova ${ }^{1} \cdot$ \\ Peter A. Th. M. Geurts ${ }^{1}$ - Hans E. Roosendaal ${ }^{1}$
}

Published online: 29 February 2016

(C) The Author(s) 2016. This article is published with open access at Springerlink.com

\begin{abstract}
In this paper, we present a theory of strategic positioning that explains scientists' strategic behavior in knowledge transfer from university to industry. The theory is based on the drivers strategic interdependence and organizational autonomy and entails three modes of behavior of scientists: mode1, mode2, and mode3 (the research entrepreneur). The results of an empirical study conducted at a research institute for nanotechnology show that, to increase the likelihood of scientists engaging in knowledge transfer to industry, scientists need to have a high need for autonomy (expressed in decision-making on collaboration with industry and join research projects) and a high need for interdependence (expressed in the need for resources such as knowledge, skills, facilities, etc.). Scientists' academic and industry orientations do not change the effect of the strategic positioning theory on the likelihood of engagement with industry, nor the likelihood of knowledge transfer. The strategic positioning theory explains $43 \%$ of the variance, i.e. there is a firm foundation for managerial practices for different scientist modes of strategic behavior.
\end{abstract}

Keywords Knowledge transfer - Mode1 - Mode2 - Mode3 - Research entrepreneur · Academic orientation · Industry orientation

\section{Introduction}

Knowledge transfer, academic entrepreneurship, and the university's third mission have become substantial parts of university institutional strategy. As Olmos-Penuela et al. (2014) show, knowledge transfer activities are now studied in the social sciences, as the social sciences and humanities became more aware of the need to transfer knowledge to

Kasia Zalewska-Kurek

k.zalewska-kurek@utwente.nl

1 University of Twente, PO Box 217, 7500AE Enschede, The Netherlands 
industry. Much has been said about universities that engage in entrepreneurial activities such as patenting, new venture creation and support, innovation network creation, etc. (for an overview of the field, see Rothaermel et al. 2007). However, this knowledge domain is still in its infancy, as witnessed by the lack of a theory that can explain which conditions lead to successful knowledge transfer from university to industry (Rothaermel et al. 2007). There is a need to explain "the determinants of research productivity and the impact of inventions and commercialization activities" (Buenstorf 2009). In this study, we seek to deliver and test a theory that draws knowledge transfer boundary conditions by scientists to industry.

The literature has mainly focused on outcomes rather than on the management of relationships between the university and industry. Entrepreneurial activities of scientists or universities are often measured by for instance number of patents, number of spinoffs, contract research, industry training courses, consulting, obtaining grants from external sources, number of graduates, or creating knowledge parks in the case of universities (Louis et al. 1989; Klofsten and Jones-Evans 2000; Arundel and Geuna 2004; Debackere and Vleugels 2005; D'Este and Patel 2007; Bekkers and Bodas Freitas 2008). While we acknowledge that knowledge transfer means much more than collaboration with industry, we focus here on scientists' behavior, and test these with engagement with industry as the primary possible outcome variable. The phenomenon of engagement in collaboration with industry implies that scientific results can be commercialized further, either by a company involved in research or by scientists. It also implies active co-creation of scientific knowledge. Perkmann et al. (2013) state that academic engagement, i.e. relationships between scientists and non-academic organizations, is far more frequent than commercialization of research, since it is closer to academic research and thus more agreeable to scientists.

In this paper, we take a managerial perspective on knowledge transfer from academia and ask the following questions: What conditions make scientists explore and exploit possibilities of alliances with industry? What are the managerial conditions for optimizing knowledge transfer in collaboration with industry?

For several decades, it has been a priority of many governments to increase knowledge transfer from academia to industry. This has been more or less successful. Some government initiatives proved to be productive; these include the National Science Foundation's engineering research centers (ERCs) in the US (Feller, Ailes, and Roessner 2002), while some-such as the UK Genomics Parks (Swan et al. 2007) have failed. These mode2 government initiatives (Gibbons et al. 1994) gave industry a central position, stressing the importance of societally relevant knowledge as a panacea to the ivory tower (mode1) research type that produces knowledge purely in the academic context. We argue that the failure of the UK initiative was caused by a mismatch between the expectations and behavior of scientists and managerial strategies and practices. The UK government approached scientists in the framework of mode2 (Gibbons et al. 1994), leaving scientists little autonomy. However, mode 2 is not the only behavior mode that can be observed among scientists (Kurek et al. 2007). The assumption that there is one and only one way to manage knowledge transfer is therefore bound to lead to failure. The notion that one size does not fit all is not new in research policy. For instance, Perkmann et al. (2011a) argue for "differentiated approaches" to university-industry interactions based on their findings that each scientific discipline needs separate management practices. In this paper, we hold that each scientist behavior mode requires a tailored management approach. 


\section{Knowledge transfer from the university to industry}

Scientists primarily seek to produce knowledge and disseminate scientific discoveries among the scientific community (Merton 1957). Transferring knowledge to industry is not necessarily in their direct interest if it is not encouraged institutionally (e.g. by funding). The literature reveals that one of the reasons scientists engage with industry is to get access to industry resources such as facilities (e.g. D'Este and Patel 2007) and knowledge (e.g. D'Este and Perkmann 2010). A study among nanotechnology scientists in the Netherlands shows that the main and significant reasons to interact with industry are to solve practical problems and to get access to industry knowledge (Dervojeda 2012). Academic entrepreneurship motivated by personal income plays a minor role in prompting academics to work with industry (D'Este and Perkmann 2010). Companies also establish relationships with universities to gain access to various types of resources (Perkmann et al. 2011b). Thus, the need to share resources is seen as a major driver for scientists to step out of their ivory tower. The question then becomes how to manage those resources and relationships to create added value.

Research reveals an increase in academia-industry joint ventures (Hall et al. 2001) as well as in joint scientific publications (Branstetter 2004; Calvert and Patel 2003; Verbeek et al. 2002). This increase is different across scientific disciplines (Klevorick et al. 1995; Landry et al. 2007), university departments (Mansfield and Lee 1996; Schartinger et al. 2001), and regions (Audretsch and Feldman 1996; Zucker et al. 1998). The distribution of academic scientists' activities in collaboration with industry is highly skewed, with just a few scientists engaged in a large number of interactions (Balconi et al. 2004; Agrawal and Henderson 2002). The existing literature on knowledge transfer provides answers to questions on the factors that influence knowledge transfer and industry engagement by exploring scientists' institutional environments such as research group characteristics (Olmos-Penuela et al. 2014), individual characteristics such as faculty quality (Perkmann et al. 2011a, b), experience with industry (Bercovitz and Feldman 2003), career stage (Bercovitz and Feldman 2003; Link et al. 2007), as well as grants and contracts with industry that enhance collaboration between university scientists and companies (Bozeman and Gaughan 2007). D'Este and Patel (2007) observed past behavior, funds raised, age, rank, and status, concluding that these individuals' characteristics have stronger impacts than the characteristics of their departments or universities. An up-to-date overview of individual, organizational, and institutional antecedents and consequences of relationships between scientists and industry by Perkmann et al. (2013) and an extensive literature analysis on research collaboration by Bozeman et al. (2013) reveal a knowledge gap concerning the management of relationships. The questions how to manage scientists' behavior and what the appropriate managerial practices have not yet been answered.

\section{Strategic positioning of scientists and hypothesis development}

Relationships between scientists, or scientific departments, and industry, as one of many knowledge and technology transfer channels, are generally established on a temporary basis between two entities with different expectations. Scientists strive for knowledge production and dissemination and pursue their career, which is not necessarily significantly enhanced by connections with industry (Van Rijnsoever et al. 2008). Companies expect access to knowledge and state-of-the-art technologies as well as applicable research results 
(Perkmann et al. 2011a, b). However difficult this collaboration might be, it has a substantial added value if managed properly. These relationships can be seen as temporary strategic alliances that are established to create value. To study them, we explored the literature on strategic alliances and integration of organizations. The literature reveals that strategic alliances are established for strategic reasons of increasing competitive advantage, organizational knowledge, and learning (Gulati 1998), as well as technology development and transfer of resources and processes between two or more organizations (Narula and Hagedoorn 1999). Perkmann and Walsh (2007) observed that strategic alliances between researchers and industry have been gradually evolving from informal ad hoc cooperation to large-scale long-term alliances. Benefits to scientists from research-industry strategic alliances include access to laboratory equipment, gaining insights that apply to academic research, and supplementing research and education funds (Mansfield 1995; Murray 2002). Eisenhardt and Schoonhoven (1996) found that alliances are more likely to be formed when both partners are in vulnerable strategic positions (i.e. in need of resources) or when they both are in strong positions (i.e. have valuable resources to share). We assume that each partner must be in the possession of heterogeneous and exchangeable valuable resources, otherwise there would be no incentive to form an alliance. As any other alliance, these alliances between scientists and industry also need proper management and organization (e.g. Gueth 2001).

Alliances can be seen as the integration of organizations, with two factors playing a role in value creation. According to Haspeslagh and Jemison (1991), the successful integration of merging organizations depends on the need for strategic interdependence (sharing of heterogeneously distributed resources and competences) and the need for organizational autonomy (making decisions about the organization, its goals, strategy, and culture). It should be stressed that the relevant factors are not strategic interdependence and organizational autonomy, but the needs for strategic interdependence and organizational autonomy. In this case, organizational autonomy describes the autonomy of scientists within the alliance of academia and industry. The authors state that these needs are a result of the merging organizations' goals, and that the successful integration of two organizations depends on their strategies for a specific integration.

The idea to analyze relationships between university scientists and industry from the perspective of temporary merging and integrating organizations was inspired by the model of Haspeslagh and Jemison (1991). While scientists clearly control fewer resources than large and complex organizations and do not develop complex strategies to pursue their ambitions, they do have goals and allocate their resources to implement various strategies to attain these goals. They also have sufficient autonomy to implement their strategies and enter into contracts with industry. The model of Haspeslagh and Jemison (1991) was adapted to the level of individual scientists, albeit as part of a department within an institute, and developed further into the strategic positioning theory, and was successfully applied in studies on knowledge production (Kurek et al. 2007; Zalewska-Kurek et al. 2010; Lyhne 2012). The results show that knowledge production differs in different behavior modes. Following up on these studies' results, we test the theory with knowledge transfer activities as new dependent variable. If the needs for resources and autonomy make a difference concerning knowledge production, they might also influence knowledge transfer. We claim that scientists' behavior in knowledge transfer can be managed by research management, which can apply appropriate managerial practices to increase knowledge transfer.

Strategic positioning theory states that there are four scientist behavior types: mode1, mode2, mode3, and mode0 (see Fig. 1). These modes are ideal types in the Weberian sense 


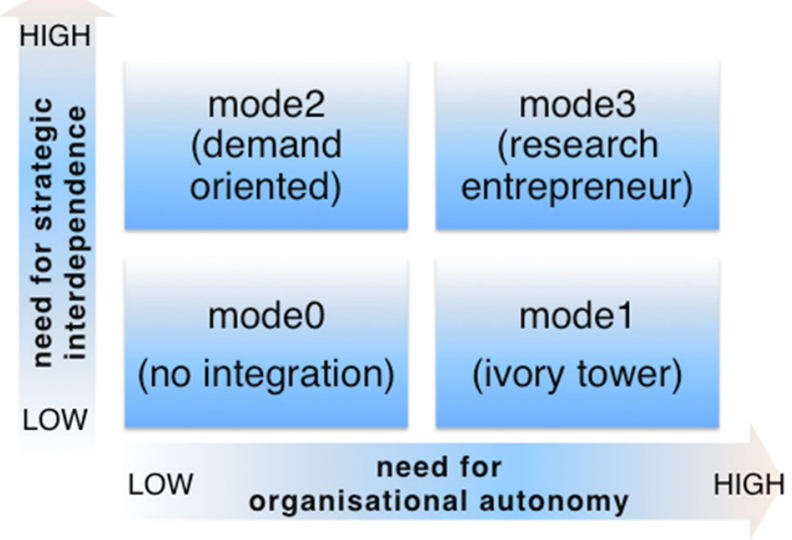

Fig. 1 Managerial modes of behavior

and are consequentially continuous because the dimensions are continuous. Mode0, which means no integration between actors, is not relevant for our purpose, and we will not discuss it further.

Mode1 is close to what is known in the literature as the ivory tower. Scientists' characterized by this mode have a high need to pursue their own goals without any need for external resources. Like Gibbons et al.'s mode1 (1994), these scientists do not engage with industry; they are interested only in pursuing their academic interests. Mode 2 scientists have a high need for external resources but a low need to make own decisions in their research. This means that these scientists will depend on their environments in developing their research more than mode1 scientists. The mode 2 type is close to Gibbons et al.'s mode2 (1994) or strategic research (Ziman 1991), where there is much involvement by government and large multinational corporations in the knowledge production system. While we use close, the modes proposed by Gibbons et al. (1994) were not based on a managerial framework, but sought to describe what the authors observed as taking place in the science system.

Mode 3 characterizes entrepreneurial scientists, who interact with their environments to share resources and are also driven by a high need for own decision-making in their research.

Assuming scientists' rationality, decisions regarding research are driven by scientists' goals. While scientists strive for maximum autonomy (Ziman 1991; Aghion et al. 2008), they might still give up some of their autonomy and might have to accept more interdependence, if this were desirable to them, e.g. to attain their research or career goals. A research direction can seek to serve a particular purpose of the industrial partner's or the institution's strategy. Blumenthal et al. (1996) show that lifescience scientists in the US receiving industry support say that their research topic choices are influenced by a project's commercial potential. Zalewska-Kurek et al. (2010) showed that the higher the need is to make autonomous decisions in research (together with a high need for strategic interdependence), the higher the knowledge production is. Here, industry is considered as a means to do research by providing access to needed resources and, often, co-creating research results. We claim that, just as in knowledge production, scientists need to make decisions 
regarding collaborative research projects to engage with industry. Projects in which scientists have very little to say are not attractive.

As outlined earlier, sharing heterogeneous resources is a necessary condition for an alliance. This approach is usually applied to commercial enterprises, but rarely explicitly and in its entirety to university research settings (Van Rijnsoever et al. 2008). Resources usually refer to human and social capital that leads to increased research collaboration (e.g. de Price and Solla 1966; Van Rijnsoever et al. 2008). External resources such as funding are seen as opportunities for new initiatives (Auranen and Nieminen 2010). Scientists who interact with industry have a high need for interdependence on their environment, because they wish to gain access to resources and to acquire visibility and a reputation (Bozeman and Corley 2004; Reagans et al. 2004; Reagans and Zuckerman 2001; Oh et al. 2006). As argued above, access to resources is the main driver for establishing relationships with industry, and we hypothesize that a higher need for strategic interdependence will lead to more engagement with industry and thus knowledge transfer. Thus:

H1: The higher the needs for organizational autonomy and for strategic interdependence are, the higher the likelihood of knowledge transfer will be.

It may be noted that this hypothesis automatically covers the other modes as well, because as we observed before, the modes are continuous. So the analysis of the data will indicate the optimum linear combination of strategic interdependence and organizational autonomy for scientists in order to be most productive in knowledge transfer. By formulating hypothesis 1 in this way, we want to stress that we expect that mode 3 scientists, or entrepreneurial scientists, are most productive in knowledge transfer, as also observed in knowledge production. The reason we do so, is that entrepreneurial scientists are more likely to create demand for their scientific product, thereby increasing the unicity of successful scientific products created in the alliance.

\subsection{The effects of academic rank and career orientation}

There are a number of supplementary and competing factors in the literature that affect knowledge transfer. A distinction is usually made between institutional characteristics and individual characteristics. In this paper, we focus on factors related to individual characteristics of scientists. Past behavior of individual scientists in participating in knowledge transfer (Bercovitz and Feldman 2003; Clarysse et al. 2011; D'Este and Patel 2007) as well as their career stage (Bercovitz and Feldman 2003; Link et al. 2007), funds raised, age, rank, and status (D'Este and Patel 2007), as well as opportunity recognition capacity (Clarysse et al. 2011) have shown some positive influences on knowledge transfer activities undertaken by scientists.

If the strategic positioning theory stands, these factors found in the literature should just add some explained variance.

D'Este and Patel (2007) found a significant positive effect of academic status on variety of interactions with industry. The authors state that the higher a scientist's rank, the more likely it is that he or she will engage in interactions with industry. D'Este and Perkmann (2010) also found that senior scientists engage more frequently in joint or contract research and consulting. Junior scientists are seen to engage in more varied interactions with industry (D'Este and Patel 2007). They suggest that this might indicate that junior scientists consider establishing relationships with industry as building their reputation, while senior scientists capitalize on their network and already gained reputation to access resources for new research directions (ibidem). 
In strategic positioning theory, academic rank (usually correlated with age in the literature) is not a separate driver of organizational autonomy, but one of the indicators of organizational autonomy, as we explain later in the measurement section. The higher the position is, the more autonomy a scientist has gained. In the literature, academic rank is seen as a separate factor with a direct effect on knowledge transfer.

Past experience in collaborative research with industry or commercialization of knowledge is seen as an influencing factor for engaging in knowledge transfer. Clarysse et al. (2011) show that scientists with entrepreneurial experience are more likely to engage in other business ventures. Experience in joint research projects with companies also increases the likelihood of continued engagement with industry (D'Este and Patel 2007).

According to strategic positioning theory, the needs for interdependence and autonomy are affected by scientists' goals and strategies of scientists. Thus, we add scientists' career orientations into the equation. A scientist's orientation refers to their attitudes towards their careers, but not exclusively to career goals. Scientists oriented towards industry either have experience in collaborating with industry or working for industry, or are inclined to work for industry. A study by Dietz and Bozeman (2005) indicates that career diversity (i.e. job experience in academia and in industry) and industry funding affect scientists' patent productivity. The evidence from the literature suggests that industry-oriented scientists will recognize opportunities for knowledge transfer and the accompanying benefits for their career. Thus:

H2: Industry career orientation positively affects the effects of both the needs for strategic interdependence and organizational autonomy on knowledge transfer activities.

Furthermore, we argue that scientists oriented only towards their scientific development are less likely to recognize collaborative research opportunities with industry and that this will negatively impact the relationship between strategic positioning dimensions and knowledge transfer. Thus:

H3: Academic career orientation negatively affects the effects of the needs for strategic interdependence and organizational autonomy on knowledge transfer activities.

\section{Methods}

\subsection{Sample and data collection}

The data for this research were collected at the MESA+ Institute for Nanotechnology at the University of Twente, the Netherlands. This large research institute is renowned in an international, competitive environment with 500 employees, of whom 275 are Ph.D.s or post-Docs. MESA+'s scientific disciplines include physics, electrical engineering, chemistry, and mathematics. Besides its scientists' expertise, the institute is well known for having excellent nanolaboratory facilities and research equipment that are also outsourced for industry use. MESA+ acquires $60 \%$ of its revenue competing for external sources. The institute, as part of an entrepreneurial university, has created an environment for spinoffs in the microtechnology and nanotechnology industry. To date, there are over 40 high-tech startups and a targeted program for cooperation with SMEs set up especially for startups. MESA+ works with startups to promote knowledge transfer. Because of this institutional support, we expect a higher likelihood of knowledge transfer activities than in a less entrepreneurial context. Individuals are more likely to get involve with industry if they are 
trained at institutions that are active in technology transfer (Bercovitz and Feldman 2008). This should only affect the overall likelihood levels of activities in strategic alliances for knowledge transfer.

The data were gathered in semi-structured face-to-face interviews with scientists. The sample of 39 respondents covered the entire spectrum of scientific positions, ranging from $\mathrm{Ph} . \mathrm{D}$. students, post-Docs, assistant professors, professors, and scientific disciplines present in the institute. Before the interviews, we checked the scientists' profiles in order to prepare tailored-made questions that investigate equivalent aspects of strategic positioning.

\subsection{Measurement of knowledge transfer}

We base our measurement of engagement in knowledge transfer here on the entrepreneurial process defined by opportunity recognition, exploration, and exploitation to create value (Singh 2001; Shane and Venkataraman 2000, 2001). Scientists collaborate with industry to support and combine academic goals with knowledge transfer by sharing resources with partners or to advance their career in academia and/or industry (Lam 2007). They may or may not be directly involved in commercialization or company formation activities, but their activities can be restricted to producing research results.

Here, we consider three broad stages of the entrepreneurial process: opportunity exploration, preparation, and exploitation (see Table 1). In opportunity exploration, scientists are interested in forming a strategic alliance that complements or is an alternative to their relationships with their peers. Opportunity exploration involves opportunity recognition steps such as getting into contact with a partner to for instance exchange knowledge or to get funding. Opportunity preparation involves the preparatory steps such as negotiating about the particular conditions of a contract and entering into a contract. Scientists explore opportunities if they actually enter into relationships with industry to conduct joint research projects or if they create a spinoff. The exploration-exploitation framework in strategic alliances was previously used in a different way that did not relate to individual entrepreneurship (e.g. Koza and Lewin 1998).

We asked the interviewees open-ended questions about their projects in general and then probed them about their current or past projects with companies or any other relationships with industry or the commercialization of knowledge via a spinoff. They were also asked about their plans regarding collaborative projects. Their answers were then coded (observed/not observed) according to the scheme outlined in Table 1 . The dependent variable takes the value of 0 if the scientist had no relationships with industry (no

Table 1 Scientists' knowledge transfer activities

\begin{tabular}{ll}
\hline $\begin{array}{l}\text { Knowledge transfer } \\
\text { concept }\end{array}$ & Indicators \\
\hline No activities (0) & $\begin{array}{l}\text { No active collaboration with industry, no history of such collaboration, no } \\
\text { intentions to collaborate in future } \\
\text { Intention to collaborate with industry }\end{array}$ \\
Exploration (1) & $\begin{array}{l}\text { Actively approached potential partners from industry or negotiated contracts with } \\
\text { partners from industry }\end{array}$ \\
Exeparation (2) & $\begin{array}{l}\text { Entered into contracts with partners from industry } \\
\text { Established a spinoff company }\end{array}$ \\
\hline
\end{tabular}


activities), (1) if they seriously plan to establish research relationships with industry, (2) if they have already actively prepared for joint projects (e.g. by entering into negotiations with a company), and 3 if they are collaborating with a company or have started their own company based on their scientific results.

\subsection{Measurement of strategic interdependence and organizational autonomy}

The needs for strategic interdependence and organizational autonomy are measured by the states of interdependence and autonomy as perceived by the scientists. In our research, these states are then evaluated, resulting in the degrees of needs for interdependence and autonomy.

A scientist's need for strategic interdependence is defined as the need for access to heterogeneously distributed strategic resources, assets, and capabilities for performing research tasks. Resources needed for research are measured as: research facilities, expertise, funds, feedback, knowledge, skills, network, and reputation.

A scientist's organizational autonomy is defined as the need for freedom from influence of the environment, freedom from external pressure in for instance formulating tasks (Dill 1958), control of sufficient resources (Collin (in Whitley 1984:12-13)) and self-governance in deciding about research, research goals, and directions (Kurek et al. 2007). We measure the need for organizational autonomy here as an objective and subjective need for organizational autonomy (see Table 2). Objective need refers to the structure of collaboration with industry and more objective aspects of autonomy, such as having a leading role in a joint project or making decisions in research such as. setting research directions, whereas the second dimension represents a perceived (thus subjective) view of how collaboration with industry affects scientists' freedom and their research (e.g. restricts research or delays publications).

An alternative measurement of the need for organizational autonomy is academic rank, as discussed in the theoretical chapter. Academic rank is considered low for non-tenure

Table 2 Indicators for strategic interdependence and organizational autonomy

\begin{tabular}{|c|c|}
\hline Concept & Indicators \\
\hline $\begin{array}{l}\text { Need for strategic } \\
\text { interdependence }\end{array}$ & $\begin{array}{l}\text { Access to knowledge and skills } \\
\text { Access to research facilities } \\
\text { Improves a scientist's reputation } \\
\text { Improves a scientist's expertise } \\
\text { Network, employment (social capital) }\end{array}$ \\
\hline \multicolumn{2}{|c|}{ Need for organizational autonomy } \\
\hline Objective & $\begin{array}{l}\text { Leading role in the project } \\
\text { Deciding on projects (incl. knowledge contribution from industry } \\
\text { partners) } \\
\text { Academic rank } \\
\text { Junior, non-tenured: Ph.D. candidate, post-Doc } \\
\text { Senior, tenured: assistant professor and higher; senior scientist }\end{array}$ \\
\hline Subjective & $\begin{array}{l}\text { Freedom in deciding on deliverables } \\
\text { Restrictions on research } \\
\text { Restrictions on publications } \\
\text { Fulfillment of all roles in the joint industry-university project }\end{array}$ \\
\hline
\end{tabular}


junior staff and high for tenured and other senior staff. Academic rank is also included in the need for organizational autonomy objective.

We asked open-ended questions about decisions in research, research projects scientists have been recently involved in, including possible collaborative projects with companies and which decisions have been made in these projects, and who made them. Questions were also directed to the reasons for entering into relationships with companies and the attractiveness of particular relationships, to indicate the need for interdependence. Scientists gave multiple answers to these questions, which were coded in a binary system $(0=$ not observed, $1=$ observed $)$. We used the answers to define indicators of the needs for autonomy and interdependence. The separate indicators were coded as low needs $(-1)$ or high needs (1). Most indicators pointed at high needs for autonomy, with a few pointing at a low need for autonomy. For instance, when an interviewee mentioned that a shortcoming of working with a company is that it can delay paper submission, this answer was coded as a low need for autonomy. In this case, a scientist accepts a company request to intervene in the publication process.

A principal component analysis was executed on the indicator sets of the need for organizational autonomy and the need for strategic interdependence. The analysis confirmed one dimension of interdependence and two dimensions of autonomy. As seen in Table 3, the need for organizational autonomy is related to scientists' position (objective) and their perception (subjective). Table 3 presents the indicator's loadings on the components and the Eigenvalues of the components.

The indicators then were compounded and normalized by dividing by the maximum number of high need indicators.

Table 3 Factor analysis for the independent variables

\begin{tabular}{|c|c|c|}
\hline & $\begin{array}{l}\text { Component } 1 \\
\text { (objective) }\end{array}$ & $\begin{array}{l}\text { Component } 2 \\
\text { (subjective) }\end{array}$ \\
\hline \multicolumn{3}{|l|}{ Need for organizational autonomy } \\
\hline Deciding about the contract & .82 & \\
\hline Leading role in the project & .64 & \\
\hline Academic rank & .82 & \\
\hline Freedom in a project & & -.67 \\
\hline Research group is able to fulfill all roles in the project & & .49 \\
\hline Restrictions on publications & & .63 \\
\hline Restriction on research & & .84 \\
\hline Eigenvalue & 1.91 & 1.67 \\
\hline \multicolumn{3}{|l|}{ Need for strategic interdependence } \\
\hline Collaboration with companies provides access to knowledge & .79 & \\
\hline Collaboration with companies provides access to facilities & .50 & \\
\hline Collaboration with companies improves reputation & .41 & \\
\hline $\begin{array}{l}\text { Collaboration with companies improves a scientist's network, } \\
\text { provides access to future employment }\end{array}$ & .57 & \\
\hline Collaboration with companies improves a scientist's expertise & .64 & \\
\hline Eigenvalue & 1.77 & \\
\hline
\end{tabular}


Table 4 Indicators for career orientations

\begin{tabular}{ll}
\hline Concept & Indicators \\
\hline Academia orientation & Aim to develop a research group \\
& Aim to excel in education \\
& Interest in advancing the field \\
& Driven by interaction with students \\
& Driven by possibilities of exploring new research \\
directions and by challenging research & Driven by academic freedom \\
Industry orientation & Goal to spin off a company \\
& Past or current employment in industry \\
& Intention to work in industry \\
\hline
\end{tabular}

\subsection{Measurement of career orientations}

Academia orientation is indicated by a scientist's goals to develop the research group, excelling in education, interaction with students, and exploring and challenging research. Industry orientation is indicated by connections with industry, since they result in goals derived from collaborating with industry. These connections are measured by past or current employment in industry or the intention to work in industry in the future (see Table 4).

\section{Results}

\subsection{Descriptive statistics}

Table 5 shows that all the entrepreneurial stages are represented in the sample. Half of the sample explored the possibilities of industry engagement and serious plans to start joint projects with a company. About $30 \%$ passed this stage and is either engaged in negotiations or already has contract research. Since nanotechnology research requires large financial resources, scientists are expected to acquire funds from external sources, and it is unsurprising that many interviewees collaborate with companies or at least intend to do so. Some of their projects are funded jointly by the government and industry.

We present the distributions of the degrees of the need for organizational autonomy (OA) and the need for strategic interdependence (SI) in the sample as cumulative distributions in Fig. 2. Since these are cumulative distributions, we can fit them with truncated normal distributions in this case, as shown by the curves in Fig. 2.

As can be seen in Fig. 2, both fits result in high $\mathrm{R}^{2}$ values, indicating sufficiently reliable fits. The mean values for the needs for OA and SI are calculated at $50 \%$ of the range of the variables, and are .46 and .31 respectively; standard deviations are .22 and .26 respectively. We see that, in our sample, about $45 \%$ of respondents are seen to have a need for autonomy higher than .5 , and somewhat less than $30 \%$ of respondents a need for interdependence higher than .5 .

We observe a gap between the distributions of the two dimensions. The scientists in the sample have a high need for organizational autonomy and, in comparison, a slightly low need for strategic interdependence. 
Table 5 Distribution of knowledge transfer activities in the sample $(\mathrm{N}=39)$

\begin{tabular}{lcll}
\hline Knowledge transfer & Frequency & $\%$ & Cumulative \% \\
\hline No activities (0) & 7 & 17.9 & 17.9 \\
Exploration (1) & 20 & 51.3 & 69.2 \\
Preparation (2) & 7 & 17.9 & 87.2 \\
Exploitation (3) & 5 & 12.8 & 100 \\
Total & 39 & 100 & \\
\hline
\end{tabular}

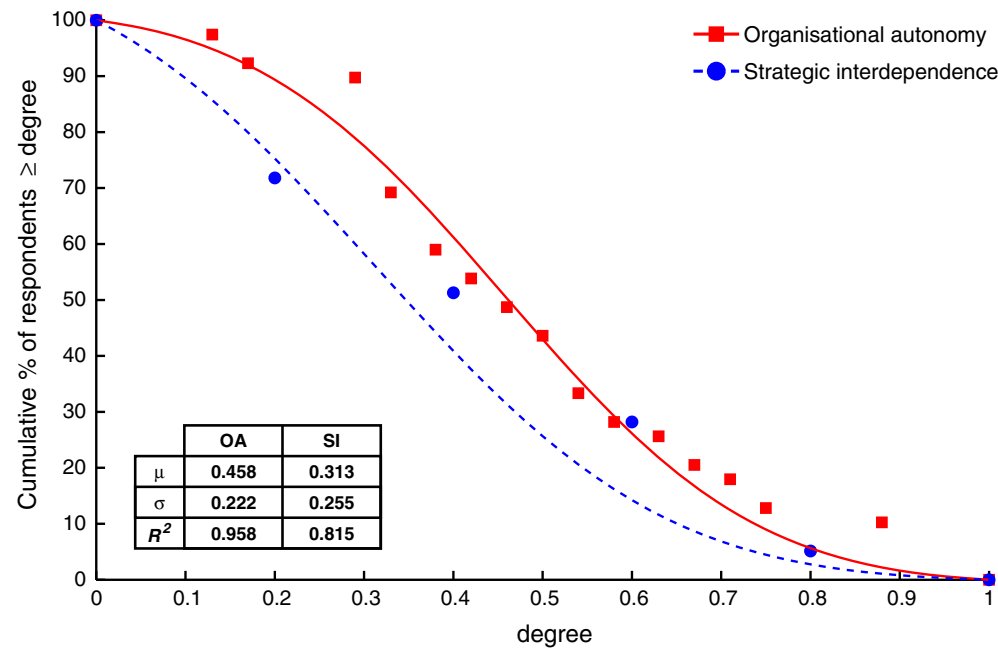

Fig. 2 Distribution of the Need for Organizational Autonomy and the Need for Strategic Interdependence. The number of observations for both variables is the same, but for the need for strategic interdependence we have a higher number of coinciding data points, resulting in a lower number of data points shown

\subsection{Strategic positioning theory}

We applied ordinal logistic regression analysis, because the dependent variable is ordinal. ${ }^{1}$ We have restricted the analysis to a linear combination of the needs for strategic interdependence and organizational autonomy, as our sample size does not allow any higher order terms in the analysis.

\footnotetext{
1 The dependent variable knowledge transfer (KT) is an interval censored variable. This means that we have only limited observational information of the position of the respondents on the KT-continuum. We have observed KT activity levels without knowing the exact position on the continuum (from 0- no activity to 3 entering contracts with industry or establishing a spinoff, see Table 1). In an ordinal logistic regression all observed stages in KT considered are in one estimate. This is done by estimating the log odds of the cumulative stages of KT:

$0 \mathrm{KT}$ not considered $\log (($ proportion $(0) /($ proportions $(1+2+3))$

1 exploration $\quad \log (($ proportions $(0+1) /($ proportions $(2+3))$

2 exploration $\quad \log ($ proportions $(0+1+2) /($ proportion $(3))$

3 exploration proportions $(0+1+2+3)$ equals 1

In Tables 6 and 8 the $\log$ odds are reported as thresholds on the dependent variable KT in which e.g., threshold 0 is the log odd of not considering $\mathrm{KT}$ at all versus the remainder stages and e.g., threshold 2 is the $\log$ odd of the previous stages versus exploitation.
} 
Table 6 Ordinal logistic regression of knowledge transfer on strategic interdependence and organizational autonomy

\begin{tabular}{|c|c|c|c|c|c|}
\hline & $\begin{array}{l}\text { Model } 1 \\
\text { Est. (SE) }\end{array}$ & $\begin{array}{l}\text { Model } 2 \\
\text { Est. (SE) }\end{array}$ & $\begin{array}{l}\text { Model } 3 \\
\text { Est. (SE) }\end{array}$ & $\begin{array}{l}\text { Model } 4 \\
\text { Est. (SE) }\end{array}$ & $\begin{array}{l}\text { Model } 5 \\
\text { Est. (SE) }\end{array}$ \\
\hline Threshold knowledge Transfer $(\mathrm{KT})=0 * *$ & 1.24 & 1.35 & -1.07 & 1.46 & -.89 \\
\hline Threshold KT $=1$ & 4.74 & 4.88 & 1.59 & 4.97 & 1.56 \\
\hline Threshold $\mathrm{KT}=2$ & 6.23 & 6.38 & 2.85 & 6.46 & 2.71 \\
\hline Strategic interdependence & $\begin{array}{l}2.11^{*} \\
(1.44)^{b}\end{array}$ & $\begin{array}{l}2.08 * \\
(1.44)\end{array}$ & & $\begin{array}{l}2.13^{*} \\
(1.45)\end{array}$ & \\
\hline Organizational autonomy objective & $\begin{array}{l}3.66^{*} \\
(1.15)\end{array}$ & $\begin{array}{l}2.87^{\mathrm{a} *} \\
(1.22)\end{array}$ & & $\begin{array}{l}3.69^{*} \\
(1.18)\end{array}$ & \\
\hline Organizational autonomy subjective & $\begin{array}{l}2.26^{*} \\
(1.08)\end{array}$ & $\begin{array}{l}2.20 * \\
(1.08)\end{array}$ & & $\begin{array}{l}2.22^{*} \\
(1.11)\end{array}$ & \\
\hline Academic rank & & $\begin{array}{l}.92 \\
(.77)\end{array}$ & $\begin{array}{l}1.75^{*} \\
(.66)\end{array}$ & & \\
\hline Academia orientation & & & & $\begin{array}{l}.13 \\
(1.57)\end{array}$ & $\begin{array}{l}2.10^{*} \\
(1.48)\end{array}$ \\
\hline Industry orientation & & & & $\begin{array}{l}.40 \\
(1.33)\end{array}$ & $\begin{array}{l}-.32 \\
(1.24)\end{array}$ \\
\hline$-2 \log$ likelihood intercept only & 87.16 & 81.33 & 22.98 & 95.35 & 60.54 \\
\hline$-2 \log$ likelihood model & 67.66 & 62.34 & 15.93 & 75.76 & 58.48 \\
\hline Nagelkerke & .43 & .43 & .18 & .43 & .06 \\
\hline Percentage correctly predicted & 56 & 51 & 51 & 56 & 51 \\
\hline $\mathrm{N}$ & 39 & 39 & 39 & 39 & 39 \\
\hline
\end{tabular}

*One-tailed $t$ test: $p<.10$

**Parallel lines tests, which were conducted to check the assumption that the dependent variable is ordinal, were positive

a Rank is not counted in the measurement of the need for organizational autonomy objective

b Standard errors are corrected for sampling without replacement in a finite population. The original estimated SE is multiplied by .96 (Cochran 1977:24)

The results are presented in Table 6 (correlation matrix in Table 7 in the "Appendix". Model 1 presents strategic positioning theory, and the coefficients show that the needs for organizational autonomy and strategic interdependence have significant positive impacts on knowledge transfer probability. Thus, strategic positioning theory is a good predictor for knowledge transfer. The increase in the need for strategic interdependence increases the likelihood of a higher knowledge transfer level (going from one threshold to a higher one); the same is true for the organizational autonomy. Thus, hypothesis 1 is not rejected. The coefficients indicate that the need for the objective organizational autonomy has a slightly bigger impact on the likelihood of engaging in knowledge transfer to industry than the need for subjective autonomy or the need for strategic interdependence. The value of Nagelkerke $\mathrm{R}^{2}$ (pseudo $\mathrm{R}^{2}$ ) is .43 , i.e. strategic positioning theory explains about $43 \%$ of the variance.

\subsection{Academic rank}

Academic rank is one indicator of autonomy and was included in the measure of objective autonomy. To test a competing theory, in lieu of autonomy we used academic rank as a separate explanatory variable (rank is thus not included in this specific measurement of the 
need for objective organizational autonomy). As seen in Model 2, rank does not have a significant impact on knowledge transfer. Organizational autonomy's impact is lower in Model 2 by almost the coefficient of academic rank. There is no change in the amount of explained variance compared to Model 1. Academic rank on its own (Model 3) explains $18 \%$ of the variance.

We also ran extra analyses to test how academic rank behaved as an independent competing factor. The results can be found in Table 8 in the "Appendix". In Model 6, academic rank plays the role of a proxy of the need for objective organizational autonomy. Rank's effect is now significant and almost twice the effect of rank in Model 2. However, the loss in explanatory power is $9 \%$. Rank as a proxy of the need for objective and subjective autonomy (Model 7) again shows a significant positive effect on knowledge transfer, but the loss in explanatory power is $19 \%$.

\subsection{Industry orientation and academia orientation}

Both the industry orientation and academia orientation had small and insignificant impacts on the likelihood to engage in knowledge transfer (Model 4). Neither of these orientations changes the independent variables' impacts on the knowledge transfer variable. This means that they do not have effects, as hypothesized. Therefore, we had to reject hypotheses 2 and 3. In Model 5, with industry and academia orientations, only academia orientation has a significant positive direct effect on knowledge transfer. Neither of the two orientations have a significant effect with academic rank as a separate variable either (model 8).

\section{Discussion}

This paper presented a theory explaining scientists' strategic behavior in university to industry knowledge transfer. With this theory of strategic positioning, we analyzed relationships between university scientists and industry as strategic alliances established with the aim of exchanging knowledge, sharing resources, and producing new research results. We tested strategic positioning theory at a nanotechnology research institute. This empirical study's primary conclusion is that strategic positioning theory is not rejected and is invariant concerning commonly used explanatory factors such as academic and industry orientations and academic rank. The theory explains $43 \%$ of the variance, which means that there is a firm foundation for managerial practices for different strategic behavior modes of scientists. We discuss such practices later in this section.

Our results show that to increase the likelihood of scientists engaging in knowledge transfer to industry, scientists need resources such as knowledge, expertise, skills, access to networks, etc. This is consistent with the literature on the motivations of scientists who engage in relationships with industry (e.g. D'Este and Patel 2007; Perkmann et al. 2009; D'Este and Perkmann 2010). In addition to this literature stream, our study also shows that scientists next to these resources also need autonomy to decide about collaboration with industry and, more importantly, about managing joint research projects. We found that mode 3 represents the optimum linear combination of the needs for strategic interdependence and organizational autonomy for scientists to transfer knowledge to industry. Similarly, the research shows that mode 2 behavior is less effective concerning knowledge transfer, because scientists place a high value on their need to decide about their research and about joining industry-university projects. These results are consistent with our 
previous work on knowledge production, in which we showed that the needs for organizational autonomy and for strategic interdependence positively influence scientists' scientific output.

Academic rank has a positive impact on knowledge transfer. We observe that the higher the rank is, the more likely a scientist is to engage with industry. Academic rank and the higher autonomy levels that accompany it mirror the experience and resources gained over the course of action. Junior scientists are bound to the one project they committed to when they started their Ph.D. research. They need the resources provided in the project, which had already been already decided on, and - to some extent-autonomy, but they most likely did not decide on the project's goals. The more senior a scientist, the more projects (and, thus, money) need to be accessed, and higher autonomy is therefore needed to decide with whom relationships should be established so as to achieve certain goals. However, on its own, academic rank does not have a large impact on the likelihood of knowledge transfer to industry; it only partially explains the likelihood. We argue that this is so, because autonomy means much more than seniority, which is just one indicator of autonomy. Deciding about research goals and the leading role in the project as well as subjective perceptions of restrictions by a company on a project and academic freedom have much stronger effects on whether or not scientists engage with industry.

In line with the literature, we assumed that experience with working in industry or an inclination to work in industry would positively affect the likelihood of industry engagement. However, our research shows that this is not the case. Affiliation with industry does not significantly change knowledge transfer. One explanation for this might be that the gain from a relationship with industry in terms of resources is already a sufficient reason to engage in such a relationship, and that specific career goals do not matter in relation to knowledge transfer. We have argued that being oriented to a career in academia will negatively affect the relationship between the needs for autonomy and interdependence, and knowledge transfer. The results show that, instead, having an academic aspiration can increase knowledge transfer. This result is in line with the results of D'Este and Perkmann (2010) in medical disciplines, since they report that academia orientation would increase the likelihood of entrepreneurial activities if academia orientation is used as a main variable. However, neither academia orientation nor industry orientation significantly change the relationship between the need for autonomy and for interdependence and the likelihood of knowledge transfer. This means that the strategic positioning theory cannot be rejected by considering these factors.

Following Haspeslagh and Jemison (1991), we argue that in order to create value in an alliance, there is a need to align managerial practices. If a research institute or university management want to enhance knowledge transfer processes and the engagement of scientists with industry, they need to manage these processes; the same goes for research policy-makers. A failure to deliver expected results could be caused by a mismatch of managerial approaches. Each of the proposed managerial modes needs a specific set of managerial practices. Based on the needs for strategic interdependence and organizational autonomy, Haspeslagh and Jemison (1991) propose three integration types: preservation for mode1, absorption for mode2, and symbiosis for mode3. They suggest a number of managerial practices that can be translated into each scientist's behavior type and can then be used by research managers. The choice of mode depends on research management's goals. We will now discuss the goals and suitable practices for each mode.

In preservation, the strategy is to explore the domain, i.e. market or industry in business terms, to learn from the organization that is being acquired. In mode1, the goal associated with this behavior type is to learn from scientists. The managerial practice most suitable for 
this type is to leave a scientist to work on their own, since they need much freedom in pursuing their research. This mode does not necessarily lead to increased knowledge transfer activities, as mode 1 scientists do not have the need to share resources with external actors. However, as the logistic regression coefficients show, the need for organizational autonomy (especially the objective component) has more impact on the likelihood of engaging in knowledge transfer. Research managers need to be able to recognize which project can and better should be done without direct industry involvement-some projects can be financed by internal resources. No industry involvement does not mean that research cannot be commercialized at a later stage.

Mode2 approximates absorption, i.e. a situation where one organization fully integrates another one to exploit the domain, so as to get a larger market share, increase performance, increase efficiency, etc. (Haspeslagh and Jemison 1991). For research managers, this type would mean that a company that wishes to fund research is familiar with the research type to be conducted but seeks facilities and scientists' expertise. These scientists engage in interactions with industry for resources and do not need as much autonomy. They might agree to research goals because it suits their goals. This approximates what is known as commissioned research. In such a situation, a company financing the research is expected to be more involved in managing the research.

The most productive mode for knowledge transfer is mode3, as seen in the results. This mode should be encouraged when it is research managers and the funding company's strategy to explore new research directions or new areas of commercialization. This mode requires more careful management, owing to the simultaneous need for high autonomy by scientists and the need for extensive resource exchange, and thus collaboration between university scientists and industry. The involvement of the company financing the project should be limited to an advisory rather than a leading role. Research goals should be proposed by scientists and discussed by all parties involved, but the scientist should lead the project.

The recognition of different modes of scientists is an important result of this study. Research managers need to realize that there is more to project governance than resource exchange and rank-scientists have different strategies concerning knowledge transfer and thus should be managed according to these strategies.

\subsection{Limitations and future research opportunities}

The main limitation of this research is the study setting. The nanotechnology institute we used is a special case of an institute that encourages many forms of knowledge transfer. The university it is associated with is an entrepreneurial university that has created more than 800 spinoffs over the past 60 years. Therefore, the institute provides facilities for business development and commercialization of research results and creates a culture that supports industry relationships. This can result in a bias. However, since we did not ask about the institutional climate or culture but about established relationships with industry and scientists' intentions, the context is of lesser importance. Nevertheless, to further develop the theory, more research is needed with an international sample and in different contexts. As noted, research institutes or universities are expected to be entrepreneurial. Following the resource-based argument, a research institute needs to support and facilitate knowledge transfer by providing appropriate resources. In the case of hard sciences, these resources are research facilities that allow the state-of-the-art research development and will attract industry to collaboration with an institute. 
The results show that, to increase the likelihood of knowledge transfer, research managers need to increase their scientists' interdependence and autonomy. These findings open up possibilities for new managerial practices to stimulate interdependence and autonomy as well as for new research to test these new practices.

\section{Compliance with ethical standards}

The manuscript has not been submitted to any other journals for simultaneous consideration, nor has it been published elsewhere. A very early version of this manuscript was presented at the University-Industry Interaction Conference (Amsterdam 2013). The authors have ensured that the manuscript complies with the ethical standards listed by the publisher.

Open Access This article is distributed under the terms of the Creative Commons Attribution 4.0 International License (http://creativecommons.org/licenses/by/4.0/), which permits unrestricted use, distribution, and reproduction in any medium, provided you give appropriate credit to the original author(s) and the source, provide a link to the Creative Commons license, and indicate if changes were made.

\section{Appendix}

\section{See Tables 7 and 8 .}

Table 7 Means, standard deviations, and correlation matrix

\begin{tabular}{|c|c|c|c|c|c|c|c|c|c|}
\hline & Mean & $\begin{array}{l}\text { Std } \\
\text { Deviation }\end{array}$ & 1 & 2 & 3 & 4 & 5 & 6 & 7 \\
\hline 1. Knowledge transfer & 1.256 & .910 & 1 & & & & & & \\
\hline $\begin{array}{l}\text { 2. Strategic } \\
\text { interdependence }\end{array}$ & .313 & .255 & .326 & 1 & & & & & \\
\hline $\begin{array}{l}\text { 3. Organizational } \\
\text { autonomy subjective }\end{array}$ & .359 & .302 & .207 & -.096 & 1 & & & & \\
\hline $\begin{array}{l}\text { 4. Organizational } \\
\text { autonomy objective }\end{array}$ & .556 & .345 & .569 & .426 & -.070 & 1 & & & \\
\hline $\begin{array}{l}\text { 5. Organizational } \\
\text { autonomy objective } \\
\text { (without rank) }\end{array}$ & .641 & .343 & .556 & .385 & -.025 & .914 & 1 & & \\
\hline 6. Rank & .380 & .493 & .420 & .358 & -.112 & .826 & .527 & 1 & \\
\hline 7. Industry orientation & .427 & .241 & -.073 & -.149 & .006 & -.152 & -.005 & -.312 & 1 \\
\hline 8. Academy orientation & .380 & .206 & .168 & .147 & .180 & .220 & .214 & .163 & -.150 \\
\hline
\end{tabular}

Table 8 Ordinal logistic regression of knowledge transfer on strategic interdependence and organizational autonomy

\begin{tabular}{llll}
\hline & $\begin{array}{l}\text { Model 6 } \\
\text { Est. (SE) }\end{array}$ & $\begin{array}{l}\text { Model 7 } \\
\text { Est. (SE) }\end{array}$ & $\begin{array}{l}\text { Model 8 } \\
\text { Est. (SE) }\end{array}$ \\
\hline Threshold knowledge Transfer (KT) $=0^{* * *}$ & .34 & -.63 & -.16 \\
Threshold KT $=1$ & 3.45 & 2.23 & 2.59 \\
Threshold KT $=2$ & 4.8 & 3.48 & 3.86 \\
Strategic interdependence & $2.63^{*}$ & $2.10^{*}$ & \\
Organizational autonomy objective & $(1.36)$ & $(1.31)$ & \\
Organizational autonomy subjective & & & \\
\hline
\end{tabular}


Table 8 continued

\begin{tabular}{llll}
\hline & $\begin{array}{l}\text { Model 6 } \\
\text { Est. (SE) }\end{array}$ & $\begin{array}{l}\text { Model 7 } \\
\text { Est. (SE) }\end{array}$ & $\begin{array}{l}\text { Model 8 } \\
\text { Est. (SE) }\end{array}$ \\
\hline Academic rank & $1.75^{*}$ & $1.41^{*}$ & $1.79^{*}$ \\
& $(.72)$ & $(.69)$ & $1.70)$ \\
Academia orientation & & & $(1.49)$ \\
& & & .71 \\
Industry orientation & & 58.78 & $71.32)$ \\
-2log likelihood intercept only & & 49.2 & 63.11 \\
$-2 \log$ likelihood model & 76.41 & .24 & .21 \\
Nagelkerke & 62.08 & 49 & 51 \\
Percentage correctly predicted & .34 & 39 & 39 \\
$\mathrm{~N}$ & 54 & & \\
\hline
\end{tabular}

*One tailed $t$ test: $p<.10$

**Parallel lines tests, which were conducted to check the assumption that the dependent variable is ordinal, were positive

${ }^{a}$ Rank is not counted in the measurement of the need for organizational autonomy objective

b Standard errors are corrected for sampling without replacement in a finite population. The original estimated SE are multiplied by .96 (Cochran 1977:24)

\section{References}

Aghion, P., Dewatripont, M., \& Stein, J. (2008). Academia, the private sector, and the process of innovation. RAND Journal of Economics, 39(3), 617-635.

Agrawal, A., \& Henderson, R. (2002). Putting patents in context: Exploring knowledge transfer from MIT. Management Science, 48(1), 44-60.

Arundel, A., \& Geuna, A. (2004). Proximity and the use of public science by innovative European firms. Economics of Innovation and New Technology, 13(6), 559-580.

Audretsch, D. B., \& Feldman, M. (1996). R\&D spillovers and the geography of innovation and production. American Economic Review, 86(3), 630-640.

Auranen, O., \& Nieminen, M. (2010). University research funding and publication performance-An international comparison. Research Policy, 39, 822-834.

Balconi, M., Breschi, S., \& Lissoni, F. (2004). Networks of inventors and the role of academia: an exploration of Italian patent data. Research Policy, 33, 127-145.

Bekkers, R., \& Bodas Freitas, I. M. (2008). Analysing knowledge transfer channels between universities and industry: To what degree do sectors also matter? Research Policy, 37(10), 1837-1853.

Bercovitz, J., \& Feldman, M. (2003), Technology transfer and the academic department: who participates and why? Paper presented at the DRUID Summer Conference 2003, Copenhagen June 12-14, 2003.

Bercovitz, J., \& Feldman, M. (2008). Academic entrepreneurs: Organizational change at the individual level. Organization Science, 19(1), 69-89.

Blumenthal, D., Campbell, E. G., Causino, N., \& Louis, K. S. (1996). Participation of life science faculty in research relationships with industry. The New England Journal of Medicine, 335(23), 1734-1739.

Bozeman, B., \& Corley, E. (2004). Scientists' collaboration strategies: implications for scientific and technical human capital. Research Policy, 33(4), 599-616.

Bozeman, B., Fay, D., \& Slade, C. P. (2013). Research collaboration in universities and academic entrepreneurship: the state-of-the-art. Journal of Technology Transfer, 38, 1-67.

Bozeman, B., \& Gaughan, M. (2007). Impacts of grants and contracts on academic researchers' interactions with industry. Research Policy, 36, 694-707.

Branstetter, L., (2004). Is academic science driving a surge in industrial innovation? Evidence from patent citations, Working Paper. Columbia University. 
Buenstorf, G. (2009). Is commercialization good or bad for science? Individual-level evidence from the Max Planck Society. Research Policy, 38(2), 281-292.

Calvert, J., \& Patel, P. (2003). University-industry research collaborations in the UK: Bibliometric trends. Science and Public Policy, 30(2), 85-96.

Clarysse, B., Tartari, V., \& Salter, A. (2011). The impact of entrepreneurial capacity, experience and organizational support on academic entrepreneurship. Research Policy, 40, 1084-1093.

Cochran, W. G. (1977). Sampling techniques. New York: Wiley.

D'Este, P., \& Patel, P. (2007). University-industry linkages in the UK: What are the factors underlying the variety of interactions with industry? Research Policy, 36(9), 1295-1313.

D’Este, P., \& Perkmann, M. (2010). Why do academics work with industry? The entrepreneurial university and individual motivations. The Journal of Technology Transfer, 36(3), 316-339.

de Price, D. J., \& Solla, B. D. (1966). Collaboration in an Invisible College. American Psychologist, 21, 1011-1018.

Debackere, K., \& Vleugels, R. (2005). The role of academic technology transfer organizations in improving industry science links. Research Policy, 34(3), 321-342.

Dervojeda, K., (2012). Dissidents of the ivory tower. Ph.D. Dissertation. University of Twente.

Dietz, J. S., \& Bozeman, B. (2005). Academic careers, patents, and productivity: industry experience as scientific and technical human capital. Research Policy, 34, 349-367.

Dill, R. D. (1958). Environment as an influence on managerial autonomy. Administrative Science Quarterly, 2(4), 409-443.

Eisenhardt, K. M., \& Schoonhoven, C. B. (1996). Resource-based view of strategic alliance formation: strategic and social effects in entrepreneurial firms. Organization Science, 7(2), 136-150.

Feller, I., Ailes, C. P., \& Roessner, J. D. (2002). Impacts of research universities on technological innovation in industry: evidence from engineering research centers. Research Policy, 31, 457-474.

Gibbons, M., Limoges, C., Nowotny, H., Schwartzmann, S., Scott, P., \& Trow, M. (1994). The new production of knowledge. The dynamics of science and research in contemporary societies. London, Stockholm: Sage Publications, SAGE Publications.

Gueth, A. (2001). Entering into an alliance with Big Pharma. Pharmaceutical Technology.

Gulati, R. (1998). Alliances and networks. Strategic Management Journal, 19, 293-317.

Hall, B. H., Link, A. N., \& Scott, J. T. (2001). Barriers inhibiting industry from partnering with universities: Evidence from the advanced technology program. Journal of Technology Transfer, 26, 87-98.

Haspeslagh, P. C., \& Jemison, D. B. (1991). Managing acquisitions: Creating value through corporate renewal. New York: The Free Press.

Klevorick, A. K., Levin, R. C., Nelson, R. R., \& Winter, S. G. (1995). On the sources and significance of interindustry differences in technological opportunities. Research Policy, 24, 185-205.

Klofsten, M., \& Jones-Evans, D. (2000). Comparing academic entrepreneurship in Europe: The case of Sweden and Ireland. Small Business Economics, 14, 299-309.

Koza, M. P., \& Lewin, A. Y. (1998). The co-evolution of strategic alliances. Organization Science, 9(3), 255-264.

Kurek, K., Geurts, P. A. T. M., Roosendaal, H. E. (2007). The research entrepreneur. Strategic positioning of the researcher on the societal environment. Science and Public Policy 34(7).

Lam, A. (2007). Knowledge networks and careers: Academic scientists in industry-university links. Journal of Management Studies, 44(6), 993-1016.

Landry, R., Amara, N., \& Ouimet, M. (2007). Determinants of knowledge transfer: evidence from Canadian university researchers in natural sciences and engineering. The Journal of Technology Transfer, 32(6), 561-592.

Link, A. N., Siegel, D. D., \& Bozeman, B. (2007). An empirical analysis of the propensity of academics to engage in informal university technology transfer. Industrial and Corporate Change, 16(4), 641-655.

Louis, K. S., Blumenthal, D., Gluck, M. E., \& Stoto, M. A. (1989). Entrepreneurs in academe: An Exploration of behaviours among life scientists. Administrative Science Quarterly, 24(1), 110-131.

Lyhne, I. (2012). Strategic environmental assessment and the Danish energy sector: Exploring non-programmed strategic decisions. Aalborg: Institut for Samfundsudvikling og Planlægning, Aalborg Universitet.

Mansfield, E. (1995). Academic research underlying industrial innovations: Sources, characteristics, and financing. Review of Economics and Statistics, 77, 55-65.

Mansfield, E., \& Lee, J.-Y. (1996). The modern university: Contributor to industrial innovation and recipient of industrial R\&D support. Research Policy, 25, 1047-1058.

Merton, R. K. (1957). Priorities in scientific discovery: A chapter in the sociology of science. American Sociological Review, 22(6), 635-659. 
Murray, F. (2002). Innovation as co-evolution of scientific and technological networks: Exploring tissue engineering. Research Policy, 31(8, 9), 1389-1403.

Narula, R., \& Hagedoorn, J. (1999). Innovating through strategic alliances: moving towards international partnerships and contractual agreements. Technovation, 19, 283-294.

Oh, H. S., Labianca, G., \& Chung, M. H. (2006). A multilevel model of group social capital. Academy of Management Review, 31(3), 569-582.

Olmos-Penuela, J., Castro-Martinez, E., \& D’Este, P. (2014). Knowledge transfer activities in social sciences and humanities: Explaining the interactions of research groups with non-academic agents. $R e$ search Policy, 43(4), 696-706.

Perkmann, M., King, Z., \& Pavelin, S. (2011a). Engaging excellence? Effects of faculty quality on university engagement with industry. Research Policy, 40(4), 539-552.

Perkmann, M., Neely, A., \& Walsh, K. (2011b). How should firms evaluate success in university-industry alliances? A performance measurement system. R\&D Management, 41(2), 202-216.

Perkmann, M., Tartari, V., McKelvey, M., Autio, E., Broström, A., D’Este, P., et al. (2013). Academic engagement and commercialization: A review of the literature on university-industry relations. $R e$ search Policy, 42, 423-442.

Perkmann, M., \& Walsh, K. (2007). University-industry relationships and open innovation: towards a research agenda. International Journal of Management Reviews, 9, 259-280.

Reagans, R., \& Zuckerman, E. W. (2001). Networks, diversity, and productivity: The social capital of corporate R\&D teams. Organization Science, 12(4), 502-517.

Reagans, R., Zuckerman, E., \& McEvily, B. (2004). How to make the team: Social networks vs. demography as criteria for designing effective teams. Administrative Science Quarterly, 49(1), 101-133.

Rothaermel, F. T., Agung, S. D., \& Jiang, L. (2007). University entrepreneurship: A taxonomy of the literature. Industrial and Corporate Change, 16(4), 691-791.

Schartinger, D., Schibany, A., \& Gassler, H. (2001). Interactive relations between university and firms: empirical evidence for Austria. Journal of Technology Transfer, 26, 255-268.

Shane, S., \& Venkataraman, S. (2000). The promise of entrepreneurship as a field of research. Academy of Management Review, 25(1), 217-226.

Shane, S., \& Venkataraman, S. (2001). Entrepreneurship as a field of research: a response to Zahra and Dess, Singh, and Erikson. Academy of Management Review, 26(1), 13-16.

Singh, R. P. (2001). Comment on developing the field of entrepreneurship through the study of opportunity recognition and exploitation. Academy of Management Review, 26(1), 10-12.

Swan, J., Robertson, M., Newell, S., Dopson, S., Bresnen, M., (2007). When policy meets practice-The problems of 'Mode2' initiatives in the translation of academic knowledge. Paper presented at the Third Organization Studies Summer Workshop: Generation and use of academic knowledge about organizations, Crete 7-9 June 2007.

van Rijnsoever, F. J., Hessels, L. K., \& Vandeberg, R. L. J. (2008). A resource-based view on the interactions of university researchers. Research Policy, 37, 1255-1266.

Verbeek, A., Debackere, K., Luwel, M., Andries, P., Zimmermann, E., \& Deleus, F. (2002). Linking science to technology: Using bibliographic references in patents to build linkage schemes. Scientometrics, 54(3), 399-420.

Whitley, R. (1984). The intellectual and social organization of the sciences. Oxford: Clarendon Press.

Zalewska-Kurek, K., Geurts, P. A. T. M., \& Roosendaal, H. E. (2010). The impact of the autonomy and interdependence of individual researchers on their production of knowledge and its impact: an empirical study of a nanotechnology institute. Research Evaluation, 19(3), 217-225.

Ziman, J. (1991). Reliable knowledge: An exploration of the grounds for belief in science. Cambridge: University Press.

Zucker, L. G., Darby, M. R., \& Armstrong, J. S. (1998). Geographically localized knowledge: Spillovers or markets. Economic Inquiry, 36(1), 65-86. 